\title{
Biocatalytic Activity of Fresh Passiflora Spp. Leaves in Enantioselective Oxido-Reduction
}

\author{
Tamburini $E^{\star}$, Costa S, Rugiero I, Sacchetti G, Guerrini A and Pedrini P
}

Department of Life Sciences and Biotechnology, University of Ferrara, via L. Borsari 46, 44121 Ferrara, Italy

\begin{abstract}
The biocatalytic activity of five species of Passiflora leaves (i.e. P. amethyst, $P$. incarnata, $P$. quadrangularis, $P$. edulis, $P$. cerulea) was tested in the reduction of the ketone "cocktail" (i.e. 5-hexen-2-one 1, acetophenone 2, cisbicyclo[3.2.0]hept-2-en-6-one 3 and 2-methylcyclohexanone 4) and in the oxidation of the corresponding alcohols "cocktail" (i.e. 5-hexen-2-ol 5, 1-phenylethanol 6, endo-bicyclo[3.2.0]hept-2-en-6-ol 7, exo-bicyclo[3.2.0] hept-2-en6-ol 8, trans-2-methylcyclohexanol 9 and cis-2-methylcyclohexanol 10). P. amethyst and $P$. incarnata show the best activity in the reduction, while $P$. quadrangularis affords low yield in reduction but gives appreciable results in oxidation towards a cocktail of model substrates. This simple screening permits to test the potential of parts of fresh plants that can be used as biocatalysts in more ecologically and economically promising transformations.
\end{abstract}

Keywords: Passiflora amethyst; Passiflora incarnate; Passiflora quadrangularis; Passiflora edulis; Passiflora cerulean; Enatioselective oxido-reduction; Biocatalytic activity

\section{Introduction}

Asymmetric synthesis remains a challenge for synthetic chemists as the demand for enantiomerically pure compounds continues to increase. Several of these compounds are potential chiral building blocks of pharmaceutically important molecules, agrochemicals, flavours and asymmetric chiral ligands [1]. Moreover the enantiomers of a number of chiral drugs may exhibit great differences with regard to pharmacodynamics, pharmacokinetics and toxicological properties [2].

In this field the biotransformations, defined as chemical reactions catalysed by isolated enzymes, microorganisms or cell cultures [3], are a "green opportunity" to obtain enantiomerically pure building blocks. The use of purified enzymes [4], whole microorganisms [5] or plant cell cultures [6], mainly at industrial scale, is limited by cost and by the difficulty to handle them, due to their great sensitivity to changes in $\mathrm{pH}$ or temperature, requirements of additional cofactors, long and tedious procedures [7]. In order to overcome these limitations, the possible use of vegetable whole organs, as leaves, without any preliminary preparation or transformation, has been considered [8].

Since the biochemical potential of plant cell cultures to produce specific secondary metabolites such as drugs, flavours, pigments and agrochemicals is of considerable interest in connection with their biotechnological utilisation [9], plants have the potential to integrate the greening of organic chemistry with the use of cheap and effective reagents.

Moreover, this methodology offers numerous advantages both in terms of time-saving, since fastidious steps of preparation, extraction, purification and multiplication of the biocatalyst are not necessary thus promoting the preservation of a maximum catalytic activity of the enzymes [10], and in terms of environment-saving, since the reactions are performed in aqueous media, at room temperature, and generate only biodegradable waste [11].

In a green context, several reports have so far described the possibility of using parts of fresh plants as biocatalysts, i.e. the reduction of aromatic aldehydes using of fresh leaves of banana and maize plants [12], the stereoselective reduction of prochiral ketones by wild tissues of South American endemic plants [13] and the bioreduction of acenaphthenequinones by using peach and carrot [14].

Passiflora commonly known as passion fruit plant belongs to the family Passifloraceae, which comprises nearly 500 species. This genus, native to Tropical America and Brazil, and widely distributed all over the world [15], is principally popular for their fruits, but, traditionally, in American and European countries leaves are largely used for tea infusion [16]. Machado and co-workers have reported the use of fruit peel of Passiflora edulis for the reduction of aromatic aldehydes and ketones, obtaining very good yields and moderate enantioselectivity [17].

In this work, we have screened the biocatalytic activity of various Passiflora spp. leaves (i.e., P. amethyst, P. incarnata, P. quadrangularis, P. edulis, and P. cerulea) using a "cocktail" of ketones (i.e. 5-hexen2-one 1, acetophenone 2, cis-bicyclo[3.2.0]hept-2-en-6-one 3, and 2-methylcyclohexanone 4) to check the reduction activity, and a "cocktail" of the corresponding racemic alcohols (i.e., 5-hexen-2-ol 5, 1-phenylethanol 6, endo-bicycloheptenol 7, exo-bicycloheptenol 8, trans-2-methylcyclohexanol 9 and cis-2-methylcyclohexanol 10) to check the oxidation activity (Scheme 1). The use of substrate cocktail has been reported in the activity fingerprint of various hydrolytic enzymes [18] and also the biological activity of thousands natural products and natural product-like molecules have been screened in silico [19-22].

The final research objective was to find new biocatalysts readily accessible from both wild and commercially available natural resources, as a sustainable alternative to traditional chemical methods.

\section{Materials and Methods}

\section{General}

5-Hexen-2-one 1, acetophenone 2, cis-bicyclo[3.2.0]hept-2-en-6one 3, 2-methyl-cyclohexanone 4, 5-hexen-2-ol 5, 1-phenylethanol 6, trans-2-methylcyclohexanol 9, and cis-2-methylcyclohexanol $\mathbf{1 0}$ are commercially available (Sigma Aldrich 'Germany). endo-Bicyclo[3.2.0]

*Corresponding author: Elena Tamburini, Department of Life Sciences and Biotechnology, University of Ferrara, via L. Borsari 46, 44121 Ferrara, Italy, Tel: 390-532-455-329; Fax: 390-532-455-715; E-mail: tme@unife.it

Received February 11, 2016; Accepted February 20, 2016; Published February 28 2016

Citation: Tamburini E, Costa S, Rugiero I, Sacchetti G, Guerrini A, et al. (2016) Biocatalytic Activity of Fresh Passiflora Spp. Leaves in Enantioselective OxidoReduction. Nat Prod Chem Res 4: 208. doi:10.4172/2329-6836.1000208

Copyright: (c) 2016 Tamburini E, et al. This is an open-access article distributed under the terms of the Creative Commons Attribution License, which permits unrestricted use, distribution, and reproduction in any medium, provided the original author and source are credited. 


\section{Scheme}

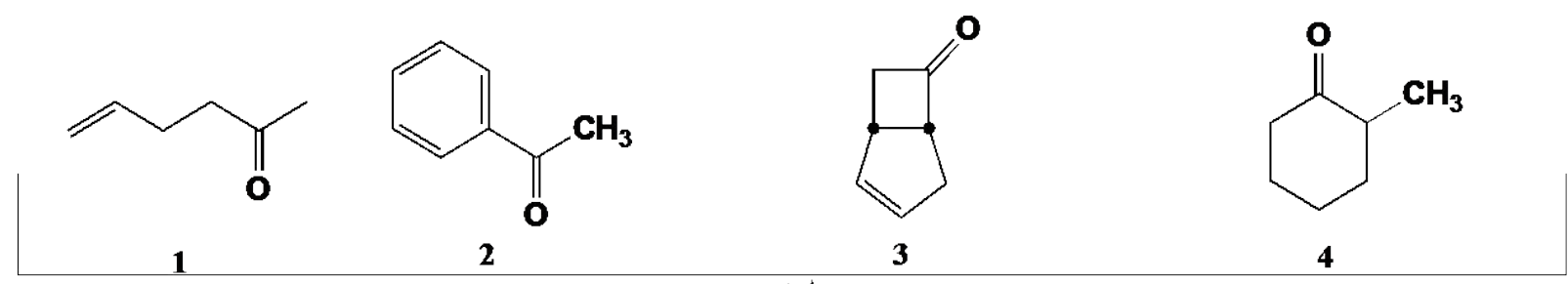

\section{Passiflora ssp leaves}

\section{oxido-reduction}

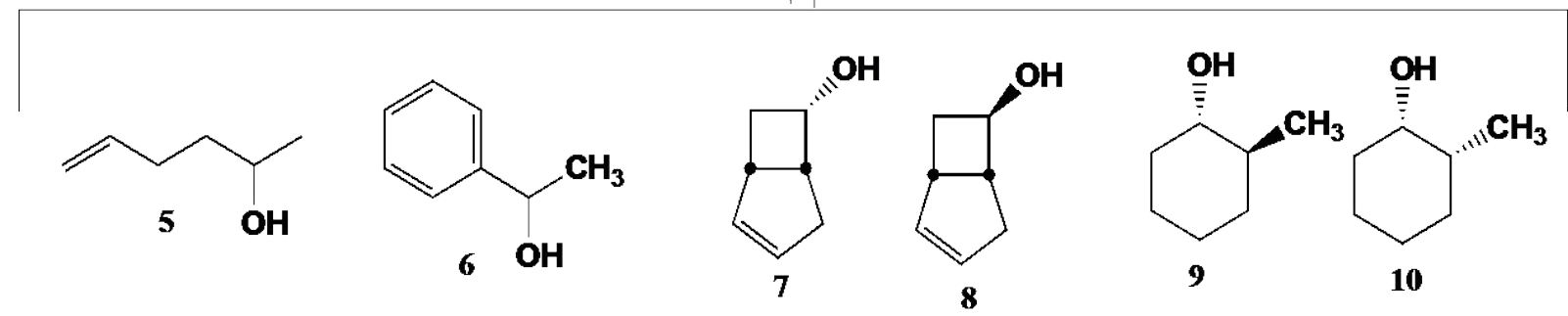

Scheme 1: Biocatalytic activity of various Passiflora spp. Leaves.

hept-2-en-6-ol 7 and exo-bicyclo[3.2.0]hept-2-en-6-ol 8 are obtained by reduction of the corresponding ketone 3 with $\mathrm{NaBH}_{4}$.

Gas chromatographic analyses were performed on a Carlo Erba GC 6000 Vega series 2 with dual Flame-Ionization Detector (FID) (Shimadzu, Japan). The analysis of the reaction mixture was achieved on Megadex DETTBS $\beta$ column $(25 \mathrm{~m} \times 0.25 \mathrm{~mm})$ containing diethyltert-butylsilyl $\beta$-cyclodextrin in OV 1701; carrier gas: helium $70 \mathrm{k}$ Pascal; injector temperature $200^{\circ} \mathrm{C}$; detector temperature $250^{\circ} \mathrm{C}$; heater temperature $75-80^{\circ} \mathrm{C}\left(0.5^{\circ} \mathrm{C} / \mathrm{min}\right), 80-100^{\circ} \mathrm{C}\left(2^{\circ} \mathrm{C} / \mathrm{min}\right), 100-200^{\circ} \mathrm{C}$ $\left(10^{\circ} \mathrm{C} / \mathrm{min}\right)$; retention time: $1,4,39 ;(S)-5,6,86 ;(R)-5,7.17 ;(S)-4,11.37$; (R)-4, 11.71; (1R,2R)-trans-9, 13.09; (1S,2S)-trans-9, 13.30; (1S,5R)- 3, 13.87; ( \pm )-cis-10, 14.08; (cis)-3, 16.29; 2, 18.62; ( \pm )-endo-7, 20.14; $(1 S, 5 R, 6 R)$-exo-8, 21.14; (1R,5S,6S)-exo-8, 22.06; $(R)-6,23.61 ;(S)-6$, 23.79, biphenyl, 26.7. Biphenyl is used as internal standard (Figure 1).

The ketone cocktail (compounds 1-4) and the racemic alcohol cocktail (compounds 5-10) were prepared mixing equal volumes of the solutions ( $0.1 \mathrm{~g}$ in $1 \mathrm{~mL}$ of DMSO) of the various compounds.

\section{Biotransformation's with plant leaves general procedure}

Five species of fresh Passiflora ssp. leaves (P. amethyst, P. incarnata, $P$. quadrangularis, P. edulis, and P. cerulea) were collected. Samples were rapidly cooled to $-80^{\circ} \mathrm{C}$ to ensure a correct preservation and avoiding foliar tissue degradation, and changes in chemical composition up to be used in the laboratory. Then, leaves were finely cut with a sterilised cutter under a sterile hood, washed with $5 \%$ sodium hypochlorite (Sigma Aldrich', Germany) and ethanol, and resuspended in water. To $50 \mathrm{~mL}$ of the suspension (1 $\mathrm{g}$ or $5 \mathrm{~g}$ of leaves), $15 \mathrm{mg}$ of chloramphenicol (Sigma Aldrich 'Germany), $1 \mathrm{~mL}$ of the appropriate reagent mixtures in DMSO (Merck, Germany) and $0.25 \mathrm{~mL}$ of a solution ( $0.1 \mathrm{~g}$ in 1 $\mathrm{mL}$ of DMSO) of biphenyl, used as internal standard, were added. The reaction mixtures were stirred on a reciprocator shaker at $150 \mathrm{rpm}$ in the dark at $34^{\circ} \mathrm{C}$. An aliquot of each reaction mixture $(1 \mathrm{~mL})$ was withdrawn and, after extraction with diethyl ether, analysed by GLC periodically $(2,4,7,10,14$, and 21 days). The results of the reduction and of the oxidation are reported in Tables 1 and 2 respectively.

\section{Results and Discussion}

The biotransformation procedure was very simple owing the easy availability of plants, the use of water without carbon source and the simple work up, because no emulsion has formed.

\section{Reduction with Passiflora spp. leaves}

The results of the reduction of the ketone cocktail are reported in Table 1. After 21 days of reduction with all Passiflora ssp. at $34^{\circ} \mathrm{C}$ the weight loss was quite high. The percentage of recovered mixture for 5-hexen-2-one 1 was only 30-57\%, higher (52-68\%) for cisbicyclo[3.2.0]hept-2-en-6-one 3 and 2-methylcyclohexanone 4 , and good (67-95\%) for acetophenone 2.

P. amethyst $(1 \mathrm{~g})$ reduced all ketones with good yields (70-94\%) but showed poor or no enantioselectivity. Surprisingly the reduction to alcohols decreased (41-71\%) with the same leaves $(5 \mathrm{~g})$ but the loss of yield is interestingly balanced by the increasing of the ees of the (R)-5-hexen-2-ol 5 (ee 27\%) and (S)-1-phenylethanol 6 (ee 52\%). Regarding the reduction of ketones $\mathbf{3}$ and $\mathbf{4}$, only the enantiomeric excesses of the $(1 R, 5 S, 6 S)$-exo-bicycloheptenol 8 and $(1 R, 2 R)$-trans-2methylcyclohexanol 9 were determined because the acetylation of the mixture, that permits the enantiomer separation of compounds 7 [23] and 10 [24], has not been carried out in this preliminary phase.

$P$. incarnata $(1 \mathrm{~g})$ reduced significantly only 5 -hexen-2-one 1 and 2-methylcyclohexanone 4 giving the $(S)$-5-hexen-2-ol 5 (52\%, ee $46 \%)$ and (1R,2R)-2-methylcyclohexanol 9 (39\%, ee 29\%), and cis-2methylcyclohexanol $10(36 \%)$, respectively. On the other hand $(S)$ methylphenyl carbinol 6 (10\%, ee 67\%), endo-bicycloheptenol 7 (15\%) and $(1 R, 5 S, 6 S)$-exo-bicycloheptenol $8(17 \%$, ee $12 \%)$ were obtained with low yields. Higher conversion but lower enantioselectivity was obtained with $5 \mathrm{~g}$ of the same leaves. Only exception was the reduction of acetophenone 2 that afforded (S)- 1-phenylethanol 6 (28\%, ee $62 \%)$.

$P$. cerulea leaves $(1 \mathrm{~g})$ did not reduce 5-hexen-2-one 1 and bicyclohepetenone 3 and afforded very low yield of alcohols $\mathbf{6}$ and 9 (6\% and $9 \%$, respectively), while the biotransformation of the ketone 


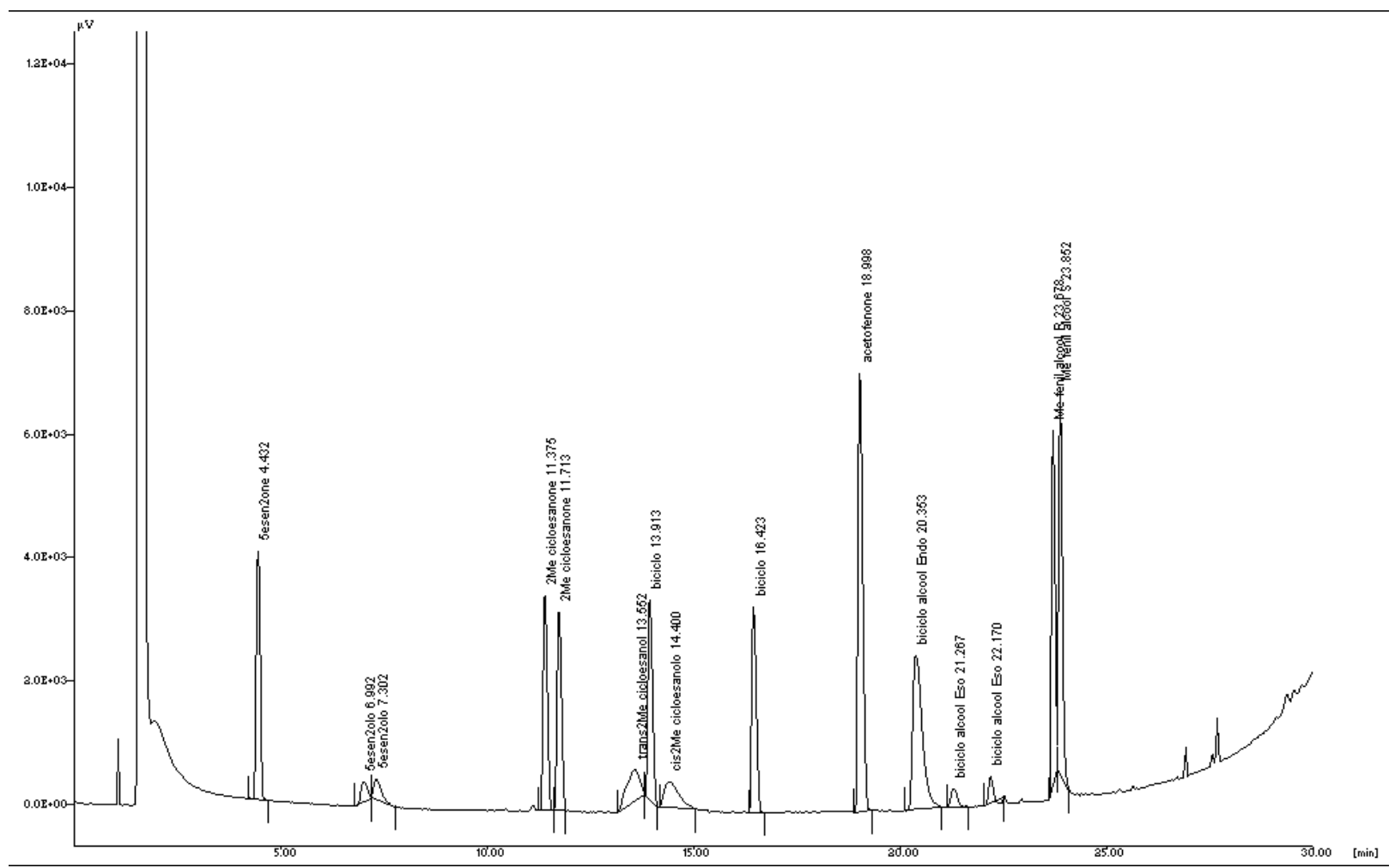

Figure 1: Gas chromatographic analysis of ketone and alcohol cocktail.

\begin{tabular}{|c|c|c|c|c|c|c|c|c|c|c|}
\hline Passiflora ssp. & g/L & days & $\begin{array}{l}\text { ketone } \\
\text { cocktail }\end{array}$ & $\begin{array}{l}\text { recovered } \\
\text { mixture }^{\mathrm{a}}\end{array}$ & $\begin{array}{c}\text { 5-hexen- } \\
\text { 2-ol } \\
5^{b}\end{array}$ & $\begin{array}{c}\text { 1-phenyl- } \\
\text { ethanol } \\
6^{b}\end{array}$ & $\begin{array}{c}\text { endo- } \\
\text { bicyclo- } \\
\text { heptenol } \\
7^{\mathrm{c}}\end{array}$ & $\begin{array}{c}\text { exo-bicyclo } \\
\text { heptenol } \\
(1 R, 5 S, 6 S)-8^{b}\end{array}$ & $\begin{array}{c}\text { trans-2-methyl- } \\
\text { ciclohexanol } \\
(1 R, 2 R)-9^{b}\end{array}$ & $\begin{array}{c}\text { cis-2-methyl- } \\
\text { ciclohexanol } \\
10^{c}\end{array}$ \\
\hline \multirow[t]{2}{*}{ P. amethyst } & 1 & 21 & $\begin{array}{l}1 \\
2 \\
3 \\
4\end{array}$ & $\begin{array}{l}30 \\
95 \\
52 \\
57\end{array}$ & $92(0)$ & $94(0)$ & 57 & $26(21)$ & $45(5)$ & 25 \\
\hline & 5 & 21 & $\begin{array}{l}1 \\
2 \\
3 \\
4\end{array}$ & $\begin{array}{l}56 \\
72 \\
68 \\
53\end{array}$ & $53(27-R)$ & $41(52-S)$ & 10 & $47(32)$ & $58(10)$ & 13 \\
\hline \multirow[t]{2}{*}{ P. incarnata } & 1 & 21 & $\begin{array}{l}1 \\
2 \\
3 \\
4\end{array}$ & $\begin{array}{l}53 \\
68 \\
55 \\
60\end{array}$ & $52(46-S)$ & $10(67-S)$ & 15 & $17(12)$ & $39(29)$ & 36 \\
\hline & 5 & 21 & $\begin{array}{l}1 \\
2 \\
3 \\
4\end{array}$ & $\begin{array}{l}57 \\
75 \\
61 \\
61\end{array}$ & $86(9-S)$ & $28(62-S)$ & 22 & $42(0)$ & $46(9)$ & 38 \\
\hline \multirow[t]{2}{*}{ P. cerulea } & 1 & 21 & $\begin{array}{l}1 \\
2 \\
3 \\
4\end{array}$ & $\begin{array}{l}30 \\
63 \\
48 \\
46\end{array}$ & -- & $6(100-S)$ & -- & -- & $9(48)$ & -- \\
\hline & 5 & 21 & $\begin{array}{l}1 \\
2 \\
3 \\
4\end{array}$ & $\begin{array}{l}54 \\
78 \\
65 \\
64\end{array}$ & $14(25-R)$ & 45 (88-S) & 12 & $11(41)$ & $44(30)$ & 18 \\
\hline P. edulis & 1 & 21 & $\begin{array}{l}1 \\
2 \\
3 \\
4\end{array}$ & $\begin{array}{l}43 \\
74 \\
62 \\
60\end{array}$ & $13(4-S)$ & $3(60-S)$ & 4 & $1(0)$ & $16(40)$ & 12 \\
\hline P. quadrangularis & 1 & 21 & $\begin{array}{l}1 \\
2 \\
3 \\
4\end{array}$ & $\begin{array}{l}49 \\
67 \\
65 \\
61\end{array}$ & $11(48-S)$ & $23(90-S)$ & 8 & $19(67)$ & $36(34)$ & 24 \\
\hline
\end{tabular}

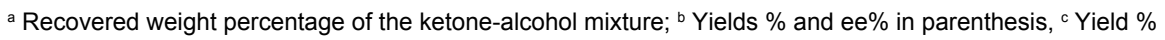

Table 1: Reduction screening of the "cocktail" of the ketones 1-4 with Passiflora ssp. Leaves. 


\begin{tabular}{|c|c|c|c|c|c|c|c|c|c|c|c|}
\hline Passiflora ssp. & g/L & days & $\begin{array}{l}\text { alcohol } \\
\text { cocktail }\end{array}$ & $\begin{array}{c}\text { recovered } \\
\text { mixture }^{\mathrm{a}}\end{array}$ & ketone $^{b}$ & $\begin{array}{c}\text { 5-hexen- } \\
\text { 2-ol } \\
5^{c}\end{array}$ & $\begin{array}{l}\text { 1-phenyl- } \\
\text { ethanol } \\
6^{c}\end{array}$ & $\begin{array}{c}\text { endo- } \\
\text { bicyclo- } \\
\text { heptenol } \\
7^{d}\end{array}$ & $\begin{array}{c}\text { exo-bicyclo } \\
\text { heptenol } \\
(1 R, 5 S, 6 S)-8^{c}\end{array}$ & $\begin{array}{c}\text { trans-2-methyl- } \\
\text { ciclohexanol } \\
(1 R, 2 R)-9^{c}\end{array}$ & $\begin{array}{c}\text { cis-2-methyl } \\
\text { ciclohexanol } \\
10^{\mathrm{d}}\end{array}$ \\
\hline \multirow[t]{2}{*}{ P. amethyst } & 1 & 14 & $\begin{array}{c}5 \\
6 \\
7 / 8 \\
9 / 10\end{array}$ & $\begin{array}{l}59 \\
82 \\
56 \\
52\end{array}$ & $\begin{array}{l}1(--) \\
\mathbf{2}(8) \\
\mathbf{3}(25) \\
\mathbf{4}(13)\end{array}$ & $100(0)$ & $92(6-S)$ & 52 & 23(23) & $59(5)$ & 28 \\
\hline & 5 & 14 & $\begin{array}{c}5 \\
6 \\
7 / 8 \\
9 / 10\end{array}$ & $\begin{array}{l}84 \\
73 \\
49 \\
56\end{array}$ & $\begin{array}{l}1(38) \\
2(23) \\
\mathbf{3}(46) \\
\mathbf{4}(14)\end{array}$ & $62(16-S)$ & $77(29-R)$ & 17 & $37(25)$ & $60(49)$ & 26 \\
\hline \multirow[t]{2}{*}{ P. incarnata } & 1 & 10 & $\begin{array}{c}5 \\
6 \\
7 / 8 \\
9 / 10\end{array}$ & $\begin{array}{l}80 \\
76 \\
60 \\
67\end{array}$ & $\begin{array}{l}1(50) \\
2(7) \\
3(41) \\
4(11)\end{array}$ & $50(47-R)$ & $93(8-R)$ & 29 & $30(7)$ & $49(39)$ & 40 \\
\hline & 5 & 10 & $\begin{array}{c}5 \\
6 \\
7 / 8 \\
9 / 10\end{array}$ & $\begin{array}{l}71 \\
64 \\
49 \\
64\end{array}$ & $\begin{array}{l}\mathbf{1}(35) \\
\mathbf{2}(24) \\
\mathbf{3}(52) \\
\mathbf{4}(17)\end{array}$ & $65(28-S)$ & $76(20-R)$ & 13 & $35(4)$ & $51(40)$ & 32 \\
\hline \multirow[t]{2}{*}{ P. cerulea } & 1 & 10 & $\begin{array}{c}5 \\
6 \\
7 / 8 \\
9 / 10\end{array}$ & $\begin{array}{l}53 \\
50 \\
43 \\
44\end{array}$ & $\begin{array}{l}1(--) \\
2(10) \\
3(56) \\
4(27)\end{array}$ & $100(0)$ & $90(0)$ & 24 & $20(9)$ & $55(40)$ & 18 \\
\hline & 5 & 10 & $\begin{array}{c}5 \\
6 \\
7 / 8 \\
9 / 10\end{array}$ & $\begin{array}{l}50 \\
46 \\
42 \\
39\end{array}$ & $\begin{array}{c}1(9) \\
\mathbf{2}(10) \\
\mathbf{3}(21) \\
\mathbf{4}(8)\end{array}$ & $91(4-R)$ & $90(0)$ & 62 & $17(25)$ & $62(38)$ & 29 \\
\hline P. edulis & 1 & 10 & $\begin{array}{c}5 \\
6 \\
7 / 8 \\
9 / 10\end{array}$ & $\begin{array}{l}63 \\
80 \\
68 \\
53\end{array}$ & $\begin{array}{l}1(15) \\
2(4) \\
3(24) \\
4(8)\end{array}$ & $85(15-R)$ & $96(3-R)$ & 59 & $17(11)$ & $56(43)$ & 36 \\
\hline P. quadrangularis & 1 & 10 & $\begin{array}{c}5 \\
6 \\
7 / 8 \\
9 / 10\end{array}$ & $\begin{array}{l}58 \\
73 \\
54 \\
58\end{array}$ & $\begin{array}{l}1(26) \\
2(40) \\
3(49) \\
4(31)\end{array}$ & $74(8-S)$ & $60(55-R)$ & 21 & $30(49)$ & $43(48)$ & 26 \\
\hline
\end{tabular}

a Recovered weight percentage of the ketone-alcohol mixture; ${ }^{b} Y i e l d s$ in parenthesis; ${ }^{c}$ Yields $\%$ and ee $\%$ in parenthesis, ${ }^{d}$ Yield $\%$

Table 2: Oxidation screening of the "cocktail" of the alcohols 5-10 with Passiflora ssp. Leaves.

cocktail with $5 \mathrm{~g}$ of the same leaves produced $(S)$-1-phenylethanol 6 (45\%, ee 88\%), (1R,2R)-2-methylcyclohexanol $9(44 \%$, ee $30 \%)$ and cismethylcyclohexanol 10 (18\%) together with low yield of $(R)$-5-hexen2 -ol 5 (14\%, ee $25 \%)$, endo-bicycloheptenol 7 (12\%), and $(1 R, 2 R)-2$ methylcyclohexanol 9 (11\%, ee $41 \%)$.

Practically no reduction products were obtained with $P$. edulis leaves $(1 \mathrm{~g})$. The only appreciable result was the reduction of 2-methylcyclohexanone 4 to $(1 R, 2 R)$-alcohol $9(16 \%$, ee $40 \%)$ and cisalcohol 10 (12\%).

Finally, $P$. quadrangularis (1g) gave low yields but good enantiomeric excesses of (S)-1-phenylethanol 6 (23\%, ee $90 \%)$, $(1 R, 5 S, 6 S)$-exo-bicycloheptenol $8(19 \%$, ee 67\%) and (S)-5-hexen-2ol 5 (11\%, ee $48 \%)$, together with endo-bicycloheptenol 7 (8\%). The more interesting result was obtained with 2-methylcyclohexanone 4 that afforded $(1 R, 2 R)$-trans-alcohol $9(36 \%$, ee $34 \%)$ and cis-alcohol 10 (24\%).

\section{Oxidation with Passiflora spp. leaves}

The results of the oxidation of the alcohol cocktail are reported in Table 2. In the case of the oxidation, the weight loss took place, as well. After 10-14 days, the weight of recovered mixture was $50-84 \%$ for the alcohols 5 and 6, and lower (39-67\%) for the alcohols 7, 8, 9 and 10.

$P$. amethyst $(5 \mathrm{~g})$ oxidized, after 14 days incubation, the racemic alcohols 5, 7 and 8 to the corresponding ketones $\mathbf{1}(38 \%)$ and $\mathbf{3}$ (46\%), respectively, leaving the (S)-5-hexen-2-ol 5 (62\%, ee $16 \%)$, bicycloheptenols $7(17 \%)$ and $(1 R, 5 S, 6 S)$-exo-bicycloheptenol 8 (37\%, ee $25 \%)$. Low yields $(<25 \%)$ were obtained with the other alcohols $(6$, 9 and 10) and in all cases using $1 \mathrm{~g}$ of the same leaves.

Also $P$. incarnata $(1 \mathrm{~g})$ oxidized with good yields 5-hexen-2-ol 5 and the mixture of bicycloheptenols $\mathbf{7}$ and $\mathbf{8}$ to give the corresponding ketones 1 (50\%) and 3 (41\%) with only a good kinetic resolution of the $R$-alcohol 5 (50\%, ee 47\%). Similar or worst results were obtained with $5 \mathrm{~g}$ of the same leaves.

P. quadrangularis oxidized all the alcohols to the corresponding ketones (26-49\% yields) leaving the unreacted $(R)-1$-phenylethanol $6(60 \%$, ee $55 \%),(1 R, 5 S, 6 S)$-exo-bicycloheptenol 8 (30\%, ee $49 \%)$ and $(1 R, 2 R)$-trans-2-methylcyclohexanol 9 (43\%, ee $48 \%)$. No enantioselectivity was obtained in the oxidation of the alcohol $\mathbf{5}$. Finally, the oxidations carried out with P. cerulea $(1 \mathrm{~g})$ and $(5 \mathrm{~g})$, and P. edulis $(1 \mathrm{~g})$ gave low yields of ketones 1-4 $(0-27 \%)$ and as much low enantiomeric excesses.

\section{Conclusions}

The use of a cocktail of ketones and alcohols allows preliminary information of oxido-reduction potential of Passiflora leaves using a simple and fast methodology that permits to test the potential of parts of fresh plants that can be used as biocatalysts in more ecologically and economically promising transformations. $P$. amethyst and $P$. incarnata appear to have a higher inclination towards the reduction with respect to other species, while towards the oxidation there is a greater regularity of behaviour (low yields and enantiomeric excesses) even if $P$. amethyst, $P$. incarnata and $P$. quadrangularis show a higher activity towards the substrate cocktail. 
Citation: Tamburini E, Costa S, Rugiero I, Sacchetti G, Guerrini A, et al. (2016) Biocatalytic Activity of Fresh Passiflora Spp. Leaves in Enantioselective Oxido-Reduction. Nat Prod Chem Res 4: 208. doi:10.4172/2329-6836.1000208

\section{References}

1. Vandenberghe A, Markó IE, Lucaccioni F, Lutts S (2013) Enantioselective hydrolysis of racemic 1-phenylethyl acetate by an enzymatic system from fresh vegetables. Ind Crops Prod 42: 380-385.

2. Yadav JS, Reddy PT, Nanda S, Rao AB (2001) Stereoselective synthesis of $(\mathrm{R})-(-)$-denopamine, $(\mathrm{R})-(-)$-tembamide and $(\mathrm{R})-(-)$-aegeline via asymmetric reduction of azidoketones by Daucus carota in aqueous medium. Tetrahedron Asymmetry 12: 3381-3385.

3. Mączka WK, Mironowicz A (2002) Enantioselective hydrolysis of 1-aryl ethyl acetates and reduction of aryl methyl ketones using carrot, celeriac and horseradish enzyme systems. Tetrahedron Asymmetry 13: 2299-2302.

4. Drauz K, Groger H, May O (2012) Enzyme Catalysis in Organic Synthesis. Volume 1. John Wiley \& Sons, Ltd., USA.

5. Bianchini LF, Arruda MF, Vieira SR, Campelo PM, Grégio AM, et al. (2015) Microbial Biotransformation to Obtain New Antifungals. Front Microbiol 6:1433

6. Murthy HN, Lee EJ, Paek KY (2014) Production of secondary metabolites from cell and organ cultures: strategies and approaches for biomass improvement and metabolite accumulation. Plant Cell Tiss Organ Cult 118: 1-16.

7. Baldwin CV, Wohlgemuth R, Woodley JM (2008) The first 200-L scale asymmetric Baeyer-Villiger oxidation using a whole-cell biocatalyst. Org Process Res Dev 12: 660-665.

8. Leroy B (2006) Botanochemistry: whole plants for asymmetric catalysis. Chim Nouv 92: 84-90.

9. Morris P, Scragg AH, Stafford A, Fowler MW (1986) Secondary metabolism in plant cell cultures. Cambridge University Press: London.

10. Fonseca AM, Monte FJQ, de Oliveira M, de Mattosa M, Cordell G, et al. (2009) Coconut water (Cocos nucifera L.) - a new biocatalyst system for organic synthesis. J Mol Catal B: Enzym 57: 78-82.

11. Cordell GA, Lemos TL, Monte FJ, de Mattos MC (2007) Vegetables as chemica reagents. J Nat Prod 70: 478-492.

12. Luna H, Hernández-Vázquez L, Reyo A, Arias A, Manjarrez N, et al. (2014) Banana and maize leaf wastes as a green alternative for the preparation of benzyl alcohols used as starting materials for fragrances. Ind Crops Prod 59: 105-108.
13. Orden AA, Bisogno FR, Giordano OS, Sanz MK (2008) Comparative study in the asymmetric bioreduction of ketones by plant organs and undifferentiated cells. J Mol Catal B: Enzym 5: 49-55.

14. Tong LP, Cui JN, Ren WM, Wang XY, Qian XH (2008) Asymmetric bioreduction of substituted acenaphthenequinones using plant enzymatic systems: a nove strategy for the preparation of $(+)$ - and $(-)$-mono hydroxyacenaphthenones. Chin Chem Lett 19: 1179-1182.

15. Vanderplank J (1991) Passion Flowers. MIT Press, USA

16. Saravanan S, Arunachalam K, Parimelazhagan T (2014) Antioxidant analgesic, anti-inflammatory and antipyretic effects of polyphenols from Passiflora subpeltata leaves-A promising species of Passiflora. Ind Crops Prod 54: $272-280$

17. Machado LL, Monte FJQ, de Oliveira MCF, de Matos MC, Lemos TLG, et al. (2008) Bioreduction of aromatic aldehydes and ketones by fruits' barks of Passiflora edulis. J Mol Catal B: Enzym 54: 103-106.

18. Goddard JP, Reymond JL (2004) Enzyme activity fingerprinting with substrate cocktails. J Am Chem Soc 126: 11116-11117.

19. Zhong Z, Liu LJ, Dong ZQ, Lu L, Wang M, et al. (2015) Structure-based discovery of an immunomodulatory inhibitor of TLR1-TLR2 heterodimerization from a natural product-like database. Chem Commun (Camb) 51: 11178-11181.

20. Ma DL, Chan DS, Wei G, Zhong HJ, Yang H, et al. (2014) Correction: Virtual screening and optimization of Type II inhibitors of JAK2 from a natural product library. Chem Commun (Camb) 51: 959.

21. Chan DS, Lee HM, Yang F, Che CM, Wong CC, et al. (2010) Structure-based discovery of natural-product-like TNF- $\alpha$ inhibitors. Angew Chem Int Ed Engl 49: $2860-2864$.

22. Leung $\mathrm{CH}$, Chan DS, Yang $\mathrm{H}$, Abagyan $\mathrm{R}$, Lee SM, et al. (2011) A natural product-like inhibitor of NEDD8-activating enzyme. Chem Commun (Camb) 47 2511-2513.

23. Fantin G, Fogagnolo M, Medici A, Pedrini P, Marotta E, et al. (1996) Microbia reduction of methyl-substituted bicyclo[3.2.0]hept-3-en-6-ones: a screening to the homochiral endo- and exo-alcohols. Tetrahedron Asymmetry 7: 277-282.

24. Fantin G, Fogagnolo M, Medici A, Pedrini P, Fontana S (2000) Kinetic resolution of racemic secondary alcohols via oxidation with Yarrowia lipolytica strains. Tetrahedron Asymmetry 11: 2367-2373. 